\title{
The Tale of the Dueling Neurosurgeons. A Contribution to the Neurosciences and Neurosurgery
}

\section{O duelo dos neurocirurgiões. Uma contribuição para as neurociências e a neurocirurgia}

\author{
Gilvan Aguiar da Silva ${ }^{1} \quad$ Elton Gomes da Silva ${ }^{1} \quad$ Seidel Guerra López ${ }^{1}$ \\ 1 Programa de Pós-Graduação em Biociências, Universidade Federal \\ da Integração Latino-Americana, Foz do Iguaçu, Paraná, Brazil \\ Address for correspondence Gilvan Aguiar da Silva, MD, Universidade \\ Federal da Integração Latino-Americana, Foz do Iguaçu, Paraná, Brazil \\ (e-mail: gilvanaguiar@hotmail.com).
} Arq Bras Neurocir 2019;38:250-252.

\author{
Abstract \\ Keywords \\ - neuroscience \\ - career in \\ neurosurgery \\ - medicine \\ - medical education \\ - career in research
}

In the present article, we elaborate a critical review of the book "The Tale of the Dueling Neurosurgeons: The History of the Human Brain as Revealed by True Stories of Trauma, Madness, and Recovery", written by Sam Kean. In our opinion, this book can contribute to the dissemination of neurosciences to the lay public, but it can also have an important role: to increase the interest of medicine students in neurosciences and research, since an increasingly lower number of students declare they have this interest. Thus, this book can be an important tool to deal with a pertinent and current issue under debate in the neuroscience research and neurosurgery communities.

Nesse artigo, elaboramos uma resenha crítica do livro "O duelo dos neurocirurgiões e outras histórias de trauma, loucura e recuperação do cérebro humano", escrito por Sam Kean, que, em nossa avaliação, pode contribuir de forma significativa para a divulgação das neurociências ao público leigo, mas que também pode atuar com a importante função de fomentar o interesse de estudantes de medicina para as neurociências e pesquisa, uma vez que um número cada vez menor desses estudantes declaram ter tal interesse. Dessa forma, esse livro pode ser um importante instrumento para uma questão oportuna e atual debatida na comunidade de pesquisa em neurociências e neurocirurgia.
Many undergraduates who have their first contact with research or scientific initiation may end up forming a misconception of what the profession really is. This occurs because, when participating in these programs, they are usually taken directly into the day-to-day research, which, as a rule, involves repetitive and monotonous activities. The initial stages of discovery, the awakening of curiosity, or the interest in answering questions, which are the pillars of science and the main motivators of researchers and scientists, are usually "skipped" or ignored.
Added to this, there is still a strong financial aspect involved in the vocation for research. Recently, the University of New York (NYU) stated that it would exempt medical students from tuition for the first year of the course. The measure, according to the Board of Directors, is an attempt to reduce the debts that students accumulate throughout the course, which end up influencing the choice of more profitable specialties to the detriment of the vocation itself, and a reflection of this, still according to the university administrators, is the ever-

Copyright $\odot 2019$ by Thieme Revinter Publicações Ltda, Rio de Janeiro, Brazil
License terms

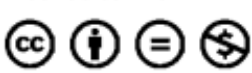

received
March 7, 2019
accepted

June 12, 2019
DOI https://doi.org/

10.1055/s-0039-1693722. ISSN 0103-5355. 
decreasing number of students opting for specialties such as Family Medicine, or even scientific research (masters and doctorates). ${ }^{1}$

Certainly, these situations do not occur only in developed countries. Latin-American countries like Brazil have shown the same problem, with a low number of researchers in the medical field. The last study on medical demography in Brazil was conducted in 2018 by Faculdade de Medicina da Universidade de São Paulo (FMUSP, in Portuguese), and it showed that only $0.5 \%$ of public-university medical graduates, and $0.3 \%$ of private-university graduates, wish to follow a career in research. ${ }^{2}$

In addition, the existence of numerous academic leagues in the different medical fields ${ }^{3}$ ends up directing the students in a pre-maturation way to the medical specialty itself, because they are mostly focused on clinical activities, being present at surgeries etc., without opportunizing that the academic knows and or evaluates first its vocations in research or teaching.

In this context, a question becomes more present: What to do to arouse interest in a career in neuroscience research, if the medical specializations (neurosurgery and neurology) seem to be much more financially promising and much more present throughout the undergraduate courses?

The book "The Tale of the Dueling Neurosurgeons: The History of the Human Brain as Revealed by True Stories of Trauma, Madness, and Recovery", written by Sam Kean, addresses historical and technical subjects regarding neurosurgery and neurosciences in general, from the point of view of a professional science writer.

Sam Kean is also the author of other bestsellers that deal with the dissemination of scientific knowledge. In 2009, he was a runner-up for the National Association of Science Writers' Evert Clark/Seth Payne Award for best science writer under the age of thirty. ${ }^{4}$ In "The Tale of the Dueling...", he tells stories that he finds curious and interesting about brain functioning, neurosurgery and the evolution of the research in this field.

However, Sam Kean has a peculiar way of spreading science; his stories are dramatic, and generate curiosity and the most varied emotions. It is not enough to say, for example, how the first surgery was performed to prove the closed head injury, the so-called contrecoup brain injury; the author instead takes the reader back to the fifteenth century, to the afternoon when King Henry II decided to take part in a joust that would cost him his life, and how this decision culminated in the meeting of two of the greatest science and neurosurgery geniuses of the time: Andreas Vesalius and Ambroise Paré (p. 36-43) ${ }^{4}$. The authors then describes with detail the research process that led to that surgery and how this fact was extremely important for the advancement of research in the history of the neurosciences.

Another example from the book is set during World War II, amid explosions and piercing shots of surgical precision, when soldiers tried to look outside a trench, and, by exposing their heads, made the skull the part of the body most susceptible to injuries during the war. These are seemingly disconnected and irrelevant facts, but have converged so that the mapping of the complex sensory cortexes of the human brain became possible (p. 107-146) ${ }^{4}$.

Another emblematic example occurs when, rather than describing how the cannibalistic habit of a particular tribe caused scientists to understand prions (Kuru disease), the author takes the reader to the wilderness in the mountainous region of Papua New Guinea, telling the intriguing discoveries and daily adventures of a neuroscience pioneer: Carleton Gajdusek (p. 155-179) ${ }^{4}$.

Another example from the book tells the story of the assassination of a President of the United States, which is related tothe discovery of chemical synapses (p. 61-75) ${ }^{4}$.

In yet another excerpt, a stuck slide may have led to the discovery of cortical maps, with the scientist winning a Nobel Prize (p. $111 \mathrm{ff}$.) ${ }^{4}$. These are only a few examples of the author's talent for capturing attention and arousing curiosity and interest for the subject.

One cannot fail to mention that the book is based on deep and extensive historical and academic research, with references to other books, scientific articles and images, such as to the National Library of Medicine, The San Diego Brain Observatory, the book "De Humani Corporis Fabrica", by Andreas Vesalius, The death of Henry II of France did not publish any Journal of Neurosurgery, among others.

The negative point observed was the general organization of the book, which in our opinion could have been done in descending chronological order, as it would help the reader form a clearer idea of how the historical evolution of the most important events involving the neurosciences occurred, but this does not invalidate the importance and quality of the book as a whole.

Thus, considering the decreasing number of medical students who declare their intention to invest in a career in research, a branch of fundamental importance in this area of knowledge, and considering that the act of arousing curiosity and pleasure for answering questions are essential motivating pillars for any researcher, the importance of this book as complementary literature in the field of medicine becomes clear, especially due to the relaxed and engaging way in which it addresses the subjects, and can act as a mitigator of the current discrepancies in relation to the intention vocational training of these professionals after their formation.

Finally, it would not be risky to think that, even a fullytrained neurosurgeon with many years of dedication to the profession, after reading this book, could even for a moment enter into an internal duel (paraphrasing the title of the book) and imagine a life as a neuroscientist.

\section{Author Contribution}

GAS had the original idea and wrote the manuscript. EGS and SGS reviewed the writing and the scientific content of the manuscript, and made suggestions regarding the topics to be approached.

\section{Conflicts of Interest}

The authors have none to declare. 


\section{References}

1 The New York Times Jornal. Surprise Gift: Free Tuition for All N.Y.U. Medical Students - The New York Times. https://www.nytimes. com/2018/08/16/nyregion/nyu-free-tuition-medical-school.html. Accessed October 10, 2018.

2 Scheffer M, Cassenote A, Guiloloux A, Miotto B, Mainardi M. 2018Demografia Médica no Brasil. São Paulo, Brasil. ISBN: 978-8587077-55-4.

3 Cavalcante ASP, Vasconcelos MIO, Lira GV, et al. As Ligas Acadêmicas na Área da Saúde: Lacunas do Conhecimento na Produção Científica Brasileira. Rev Bras Educ Med 2018;42(01):199-206. Doi: 10.1590/ 1981-52712018v42n1rb20170081

4 ZAHAR EDITORA. Sam Kean. https://zahar.com.br/autor/samkean. Accessed October 14, 2018. 